\title{
Integration of Economic Shifts in the European Development in the Second Half of the XXth Century
}

\author{
Submitted 09/01/19, 1st revision 03/03/19, 2nd revision 10/04/19, accepted 02/06/19 \\ Vlasova G.B. ${ }^{1}$, Vlasov V.I. ${ }^{2}$, Denisenko S.V. ${ }^{3}$, Kolesnick V.V. ${ }^{4}$
}

\begin{abstract}
:
Purpose: The article analyzes those processes having initiated the development of the European and political integration. The article is focused on the genesis and the development of the Council for Mutual Economic Assistance, the European Union, NATO and the Warsaw Pact.

Design/Methodology/Approach: By applying the system analysis method as well as dialectical and historical methods, the authors have attempted to reveal the significance of those events resulted in modern international organizations establishment.

Findings: Authors have analyzed the XX century trends in integration and highlighted Western Europe as the most productive in the process. Authors have provided the USSR and post-USSR integration overview to reveal the European development patterns.

Practical Implications: The research results may be implemented into political and educational courses as well as to be used by official authorities.

Originality/Value: The main contribution of this study is the deep integration trends" analysis and the emphasis on the unipolar-bipolar-multipolar world's concept.
\end{abstract}

Keywords: Integration, block strategy, the Council for Mutual Economic Assistance, the European Union, NATO and the Warsaw Pact.

JEL codes: F02, F15, H11, K33, N14.

Paper Type: Research article in Special Issue Dedicated to Russian Economy.

Section 5: Law, Constitutional, Social.

\footnotetext{
${ }^{1}$ Associate Professor, Doctor of Law, Department of Theory and History of State and Law. Rostov State University of Economics (RSUE).Rostov-on-Don, E-mail: vlasovagb@mail.ru ${ }^{2}$ Professor, Doctor of Philosophy, Department of History of the theory of law and state. Russian State University of Justice, Rostov-on-Don, E-mail: vlasovvi@mail.ru ${ }^{3} \mathrm{PhD}$ in International Law, Russian State University of Justice, Rostov-on-Don, E-mail: S.v.denisenko@bk.ru

${ }^{4} \mathrm{PhD}$ in Civil Law, Russian State University of Justice, Rostov branch. Rostov-on-Don.
} 


\section{Introduction}

Modern integration processes have long history. The world knows different organizations that appeared in the European and Afro-Asian regions. However, the processes that have started in Europe in the late 40-s of the XX century have no analogues in the past. Under the bipolar world the organizations that had a great impact on the further human society development, were established. Studying their formation and development is very important and will attract the researchers' attention for a long time. The experience accumulated by the Council for Mutual Economic Assistance, the European Union, NATO and the Warsaw Pact is important to develop the relationships in the context of The Eurasian Economic Community, The Shanghai Cooperation Organization and the Collective Security Treaty Organization. Today the integration processes influence substantially the development of the separate states. Gradually the world is becoming united and the isolation cannot provide successful development.

The Russian scientists Bogaturov (2007), Marchenko (2012), Protopopov (2001) paid much attention to the integration processes development in Europe in a number of their works. In this connection it is necessary to research these issues more attentively.

It should be mentioned that foreign experts pay much attention to the integration issues as well (Dinan, 1999; Kennedy, 1987). The Russian silence is lagging in this respect. Studying integration processes taking place in the world in a whole and in Europe in particular, demand more efforts from the part of the Russian scientists. The integration processes which took place in the XX century date back to the XIX century. Great Britain was the first state to be involved into the integration processes. The government of this country was the first to realize the necessity to refuse from imperial colonialism. The Commonwealth established by the British proved its vitality. And what is more important nobody has managed to repeat this experience in such a spatial and temporal scale yet.

In the second half of the XX century in the European subcontinent the integration processes took place in two forms: economic integration in the frame of the Council for Mutual Economic Assistance and the European Economic Union and military and political in the frame of NATO and the Collective Security Treaty Organization. The western variant turned out to be more sustainable and prospective. And vice versa the East European integration eventually failed. The latter can be referred to its totalitarian nature, but the narrow-mindedness of the Soviet leadership also played an important role.

New stage of the integration processes began after the socialism system crash and the Soviet Union collapse. The European Union formation was a qualitatively new step on this way (Michalopoulos \& Tsermenidis 2018; Thalassinos \& Dafnos, 2015). 
The integration processes also began within the CIS. The formation of the Union State of Russia and Belarus and the Eurasian Economic Community proved it.

\section{The International Integration Formation Experience}

One should not think that the integration processes were started in the world only in the mid-XX century. The desire to form major state formations can be traced since the Ancient world epoch. Yet in the VI-IX centuries BC the Ancient Persian Empire encompassing the territory from the west to the east from Asia Minor to Afghanistan and Pakistan including Transcaucasia in the north and Egypt in the south existed. On the turn of the first millennium BC and the first millennium AD the Roman Empire, which had united the Mediterranean and Western Europe, was formed. In the age of the early Middle Ages, Byzantium, the Empire of Charlemagne, the Arab Caliphate, Kievan Rus existed. The mature middle Ages became the epoch of Mongol conquests and the heyday of the Ming dynasty's Chinese Empire. The Renaissance was the time of great geographical discoveries due to which the colonial empires the Spanish and the Portuguese, which started the Latin America - appeared. In the XVIII century the Russian Empire declared about itself, at that moment it comprised the spaces in the Eastern Europe, Northern Asia and American Alaska. In the XIX century the USA were fully formed, and Great Britain and France created their colonial empires.

It is necessary to note that the XIX century - the first half XX century colonialism was quite an ambiguous phenomenon. It was not just the conquest of the weak by the strong, but it was very powerful process of mutual influence, this process provided the peoples of colonies new knowledge, new spirituality and new law.

The Great Britain leadership was the first to realize that their imperial domination in the colonies was not eternal, earlier or later the conquered peoples would declare about their rights. "The Imperial Commonwealth" was first spoken about in the 60-s of the XIX century, in 1884 the term "Commonwealth of Nations" replaced it. And in 1917 the term British Commonwealth of Nations started to be used, it meant the association of the United Kingdom with the Australian Union, Canada, the Union of South Africa and New Zealand. This formation was finally constituted by the Westminster Statute of the 11 December 1931 that formally abolished the subordination of the above-mentioned dominions to Great Britain and recognized them as fully equal states. Up to 1947 the Commonwealth was a union of states united with Great Britain by the personal union (and still in 16 Commonwealth states the official head of the state is the British monarch represented by GovernorGeneral).

In 1946 "British Commonwealth of Nations" was renamed "Commonwealth". In April 1949 the declaration that is the document that established the Commonwealth existence in its present form was adopted in London. It was the first experience of modern integration. Today the Commonwealth includes 53 states with the population 
2.2 billion people. The Commonwealth membership is voluntary, and it means the possibility to join or to leave this organization freely. The Commonwealth, being unique, exists under two opposite trends, on the one hand, it is nationalism exacerbation, on the other the desire to form global and regional formations. In these circumstances the Commonwealth will be evolving, and it is becoming clear, that major changes taking place in the Commonwealth, which is a social and political laboratory today, are of global importance. The most acute issue of the current state of the Commonwealth is differentiated development levels of Great Britain, Australia, Canada, India and New Zealand on the one hand, and several states of the Afro-Asian region (as well as Oceania), on the other one.

Thus, Great Britain was the first state to be involved into the XX century integration processes. These integration processes have developed in three directions:

Firstly, under the bipolarity the West and the first the USA started to establish military and political blocks after the end of the Second World War.

Secondly, the USSR responded by establishing the economic organization and military and political union of the social countries. Both organizations were of totalitarian nature.

Thirdly, powerful economic interstate organizations started to be established in the Western Europe, in Americas and in the South-East Asia.

All these processes were accompanied by the collapse of the colonial empires and a crash of the socialism world system. The latter circumstance resulted in the transition from the bipolar world to the unipolar one and then to the multipolar one. It should be stressed that this multipolar world system was formed in 1648 due to conclusion of the Peace of Westphalia following the Thirty Years War and had existed for about 300 years with some modifications.

If the multipolar world was understood as a structure of the international relations "with several (four and more) the most influential states comparable to each other in terms of the aggregate potential of their complex (economic, political, military) influence, the bipolar world meant the progress of only two members of the international community (in the postwar years - the Soviet Union and the USA) in terms of this aggregate indicator for each of these states (Bogaturov, 2007).

It should be mentioned, that the bipolar world was a very sturdy construction based on the parity of the military forces of the USSR and the USA. However, in 19901991 the social world collapsed and one of the most important causes of this collapse was the failure of those integration changes which were undertaken in the USSR. In this connection it is necessary to pay attention at how the mentioned above integration processes were developing in the West and in the East. 


\section{Integration Processes in the 50s -60s of the XX Century}

In June 1947 the United States Secretary of State George Marshall made some proposals to overcome postwar economic problems in the Western Europe. Soon these proposals started to be called "Marshall Plan". At the end of June-July 1947, consultations on the Marshall Plan were held in Paris, and on the $12^{\text {th }}$ July the conference to discuss the Marshall Plan took place. The Organization for European Economic Co-operation was established there, later it was reorganized into the Organization for Economic Cooperation and Development (OECD). But this organization performed only coordinating functions and could not bring the Europe economic revival processes to the supranational level.

Together with the beginning of the uniting processes in the Western Europe the creation of the strong system of the bilateral unions among the states of the Central and South-East Europe took place. However, the formation of the new economic structure demanded the transition from the bilateral cooperation to the multilateral one. In January 1949 it resulted in establishing of the Council for Mutual Economic Assistance, whose members were the European socialist countries (except Yugoslavia, that started to participate in some structures of the Council for Mutual Economic Assistance since 1960-s). In 1956 the German Democratic Republic joined the Council for Mutual Economic Assistance, and then Mongolia, Vietnam and Cuba joined it.

In 1950 the Foreign Minister Robert Schuman proposed to the Federal Republic of Germany government to establish a union on coal and steel production under the leadership of the highest interstate body. In the course of the negotiations on the $18^{\text {th }}$ April 1951 France, the Federal Republic of Germany, Spain, Belgium, the Netherlands and Luxembourg signed the treaty on establishing of the European Coal and Steel Community. It was the first step towards the European Union. It was easier due to the establishing of the economic union among Belgium, the Netherlands and Luxembourg in 1948, named Benelux. Thus, in the end of the first half of the XX century two powerful economic formations started to be formed in the European subcontinent.

However, this process was complicated due to the block strategy of the USA and the USSR. In March 1948 the Brussels Pact among Great Britain, France and the Benelux countries were signed, it was a treaty on cooperation and collective defense. A year later the USA under their own leadership established on an ongoing basis a military and political block (analog of coalition). To perform it the international conference was summoned in Washington on the 4th April 1949 and on the same day the USA, Canada, Great Britain, France and the Benelux countries signed the North Atlantic Treaty (NATO).

The establishment of ANZUS Security Treaty - Australia, New Zealand, United States followed NATO in 1951. The Manila Pact was signed by the USA, Great 
Britain, France, Australia, New Zealand, Pakistan, the Philippines and Thailand in 1954. Later another block, CENTO, was constituted by the UK, Turkey, Iran and Pakistan.

The USSR leadership could not stay indifferent looking at the processes of the block strategy implementation by the Western states and as soon as the Federal Republic of German joined NATO in May 1955, the Treaty of Mutual Assistance among the USSR, Albania. Bulgaria, Hungary, the GDR, Poland, Romania and Czechoslovakia were signed on the 14th May 1955 in Warsaw, which went down in history as the Warsaw Pact. Thus, the bloc standoff was finalized. It should be said that this opposition was nonequilibrium. The Warsaw Pact Organization was purely European formation. It was impossible to establish similar union in Asia. Moreover, the relationships with China worsened in the late 1960-s. All these facts influenced the USSR and other social states' development.

At the same time the economic integration processes kept on developing. In May 1955 at the meeting of the France, the Federal Republic of Germany Italy and the Benelux countries representatives in Messina (Italy) it was decided to establish the expert committee to develop the concept of economic integration of the Western European countries, and it become a mainstream. And in 25 March 1957 in Rome the above-mentioned states signed the agreement on establishment of the European Economic Community, which went down in history under the name "Common Market".

Relying on the neutral European states (Austria, Switzerland, Sweden and others) in 1959 Great Britain initiated the establishment of the European Free Trade Association (EFTA). Eventually "The Common Market" turned out to be stronger. In 1969 it was transformed into the European Community; it meant the end of the first stage of the West European integration. In 1973 Great Britain, Ireland and Denmark joined the European Community.

Unfortunately, the Council for Mutual Economic Assistance development was less successful. The USSR leadership degraded both in political and economic terms. After the Hungarian events in 1956 a certain progress in the economic development of Hungary, Czechoslovakia and Yugoslavia occurred. The USSR gained the experimental sites in the Central and the South-East Europe whose experience would have allowed the USSR to perform the turn that did China under Deng Xiaoping on the turn of 1970-s -1980-s. It could have brought about strong integration of the socialist commonwealth. But having failed the 1964-1965 Kosygin reforms, the USSR leaders undertook meaningless intervention in Czechoslovakia in 1968 and failed all attempts to build socialism with a human face. And the course on constant expansion of the "world socialist system" turned out to be adventures in Asia and Africa that together with arm race resulted in huge expenses. As a result, the development of the West European integration was ascending, the integration in the 
East Europe finished with "velvet" revolutions, the Warsaw Pact and the Council for Mutual Economic Assistance were dissolved, and in 1991 the USSR collapsed and later did Yugoslavia and Czechoslovakia.

\section{The 1990s Integration}

In the 1990-s new wave of the integration processes started in Europe. A few months before the FRG and the GDR were united on the $19^{\text {th }}$ June 1990 the representatives the Benelux countries, France and the FRG signed the border crossing convention in the Schengen castle (Luxembourg). In November 1990 Italy joined this convention, Spain and Portugal in 1991, Greece in 1992, Austria in 1995, and all Scandinavian countries joined in 1996.

As far as the achievements of the integration processes were evident, the European community countries went to the conclusion that it is necessary to transform it into an integration formation of higher level; the European Union became such a formation. In the second half of 1991 - the beginning 1992 new treaty was finalized and agreed in the city of Maastricht (the Netherlands). And on the $27^{\text {th }}$ February the European Union Treaty was signed. As a result, economic and currency unions among the European countries were complemented with the political union. The European Union itself combined the elements of both the confederation and the federation, but its characteristics more corresponded to the federative type formation. The Maastricht Treaty came into force on November 1, 1993 after being ratified in the parliaments of the member-states.

In the mid-90-s the integration processes became one of the mega trends of the global development. This trend was manifested in many regions of the world and in different forms, sometimes very different from those having taken place in West Europe. The Association of South East Asian Nations (ASEAN), Asia Pacific Economic Council (APEC), North American Free Trade Zone (NAFTA) and South Common Market (MERCOSUR) are such formations.

The USSR collapse and the CIS formation started the development of different formations on the post Soviet Union territory. The CIS turned out to be a very inefficient formation. However, the development of the integration relation was taking place within the CIS. In particular, the relation between Russia and Belorussia were developing. In 1995 Treaty of Friendship, Good Neighborhood and Cooperation between the Russian Federation and the Republic of Belarus was signed in Minsk. In 1996 the Commonwealth of Belarus and Russia was formed. In 1997 it was transformed into the Union of Belarus and Russia, and in December 1999 both countries signed the treaty to form the Union State.

In 1997 Georgia, Ukraine, Azerbaijan and Moldova signed an agreement on the formation of the union called GUAM. The states, that had joined the union, declared that they would cooperate in the economic and political spheres in the frame of the 
Euro-Atlantic Partnership Council. In 2000 Russia, Belarus, Kazakhstan, Kyrgyzstan and Tajikistan simultaneously signed the Treaty on the Eurasian Economic Union in Astana.

\section{Conclusion}

To sum up the integration processes development in the second half of the XX century it is possible to say that the most significant results were obtained in the Western Europe. The establishment and development of the European Union prove it.

In its turn those integration processes, which were initiated by the USSR failed. While bipolar world that had been formed in the late 40-s - early 50-s demonstrated sustainability and prevented the humankind from a new world war. The dissolution of the CMEA and ATS, the collapse of the USSR resulted in the further expansion of NATO and the EU. However, the attempt to establish the unipolar world was the main negative aspect of these changes. The development of the Commonwealth, ASEAN, the European Union, the rise of China and Russia made the unipolar world impossible. However, this in its turn means the return to the multipolarity, which can turn out to unpredictable in many aspects. In such a situation the only way for the mankind development is to develop integration formations aimed at its rallying.

\section{References:}

Bogaturov, A.D. 2007. The system history of international relations in two volumes. Moscow, Culture Revolution, Vol 2, 17-23.

Dinan, B. 1999. Ever Closer Union: An introduction to European integration. Boulder, Lynne Rienner, 597.

Kennedy, P. 1987. The Rise and Fall of the Great Powers: Economic Change and Military Conflict from 1500 to 2000. New York, Random House Publishers, 677.

Marchenko, M.N. 2012. The legal system of the European Union. Moscow, INFRA-M, 704.

Michalopoulos, G., Tsermenidis, K. 2018. Country Risk on the Bank Borrowing Cost Dispersion Within the Euro Area during the Financial and Debt Crises. International Journal of Economics \& Business Administration, 6(4), 76-92.

Protopopov, A.S., Kozmenko, V.M., Elmanova, N.S. 2001. History of international relations and Russian foreign policy (1648 - 2005). Moscow, Aspect-Press Publishing, 344.

Thalassinos, I.E. and Dafnos, G. 2015. EMU and the process of European integration: Southern Europe's economic challenges and the need for revisiting EMU's institutional framework. Chapter book in Societies in Transition: Economic, Political and Security Transformations in Contemporary Europe, 15-37, Springer International Publishing, DOI: 10.1007/978-3-319-13814-5_2.

Tolstukhina, A.Yu. 2012. Commonwealth of Nations: A Reappraisal of Opportunities. Asia and Africa Today, 7, 53-57. 